\title{
Learning Aqeedah Students who Learned with the Point Conterpoint Learning Model in Integrated Islamic Junior High School in Deli Serdang 2019-2020
}

\author{
Zultoni Lubis ${ }^{1}$, Abdul Hasan Saragih ${ }^{2}$, Ibrahim Gultom² \\ ${ }^{I}$ Master Student in Universitas Negeri Medan (Unimed), Medan, Indonesia \\ ${ }^{2}$ Lecturer in Universitas Negeri Medan (Unimed), Medan, Indonesia \\ lubistoni8@gmail.com
}

\begin{abstract}
The aim of this study is to find out learning aqeedah students by using point counterpoint learning model. This research was conducted at Deli Serdang IT Middle School, Percut Sei Tuan District. Deli Serdang Regency, North Sumatra Province. This research was conducted in Odd semester of the 2019/2020 school year with treatment given 4 meetings. For one meeting, it took $2 \times 40$ minutes. The results of research and discussion that has been stated previously, then in this study it can be concluded that the Aqeedah learning outcomes of students taught with the Point Conterpoint model are higher than students taught with expository learning models.
\end{abstract}

Keywords: aqeedah; counterpoint; learning model

\section{Introduction}

The issue of education that is of concern at the moment is that most students are not able to connect between what they are learning with how it is used in real life. This is due to the learning they received emphasizes the level of memorizing the material without being followed by deep understanding or understanding and application in the environment, which can be applied when they are faced with new situations in their lives. (Muslich, 2007: 40)

But in the improvement of Indonesian education, it is also important to realize that no matter how good the curriculum is, how complete the facilities are, and the teacher controls the teaching and learning process, there is nothing meaningful if the students are not serious in their learning activities. In line with that Hudojo (Trianto, 2009: 19) states "a good learning system that has characteristics: (a) students are actively involved in their learning. Students learn material (knowledge) meaningfully by working and thinking, and (b) new information must be linked to previous information so that it integrates with the schemes that students have. "This means that the students themselves determine the level of learning outcomes.

Furthermore according to George J. Mouly (Trianto, 2009: 9) that "learning is basically a process of changing one's behavior thanks to the experience". Learning is a complex event, many factors and conditions are involved. Each factor is closely related to other factors and together as well as individually determines how the learning process takes place and how the level of learning outcomes achieved. The influence of these factors, not only on the process of ongoing learning activities but also affects the learning outcomes themselves. Because of the learning implementation process, learning outcomes will be obtained later.

In order to improve the learning outcomes of Aqeedah moral which have not been achieved properly, various efforts can be made to improve student learning outcomes. One effort is made to improve the quality of learning by applying better learning models. Learning activities are the main thing in education that cannot be separated from the role of teaching staff. The ability of teaching staff to master learning technology to plan, design, implement and evaluate and conduct feedback is an important factor in achieving learning objectives. The ability of teachers to master learning material, the use of media, the determination of learning 
models and the selection of teaching methods is an effort to expedite the learning process and improve results in achieving learning objectives (Hamalik. 2003: 56).

Based on the discussion and survey results of researchers at AL-Hijrah IT Middle School and Salsabila IT Middle School, the learning model used so far is a conventional learning model that tends to be centered on the teacher and does not involve the role of students so that learning outcomes of Aqeedah have not been satisfactory. In connection with the above problem, in this study an effort to improve the learning outcomes of Aqeedah moral was proposed to presents a Point Conterpoint learning model. Supported by research on expository conducted by Sahat Siagian and Paimin Tanjung (2015: 56) the science learning outcomes of students who were taught with discovery learning models were higher than the science learning outcomes of students who were taught with expository learning models with $\mathrm{F}^{\text {count }}=6.36>\mathrm{F}^{\text {table }}=3.98$, teachers are only limited to using varied lecture methods and assignments to students. Operationally, the teacher explains the material to students and then provides examples in real life. After completing explaining the material, the teacher tells students to work on the questions contained in the package book and worksheets independently. Students are then told to come to the front of the class one by one to give answers to each question they do. so the learning process does not vary, the teacher does not utilize a learning model that is able to make the learning process more interesting.

Based on the description above, there appears to be a gap between real conditions and expectations. The main gap of the subject is the initial condition of learning outcomes Aqeedah. From the documentation of the value of religious subjects from 2013/2014 the same as Aqeedah moral 2016/2017 school year, as in table 1.

Table 1. Learning Results for Aqeedah Ahlak Subjects Competency Standards

\begin{tabular}{|l|l|c|c|c|c|c|}
\hline \multirow{2}{*}{ No } & \multirow{2}{*}{ School year } & \multicolumn{3}{|l|}{ Student Value Range } & \multirow{2}{*}{ Total students } \\
\cline { 3 - 6 } & & $\leq 6,0$ & $6,1-7,0$ & $7,1-8,9$ & $9,0-10$ & \\
\hline 1 & $2013 / 2014$ & 10 & 50 & 50 & 10 & 120 \\
\hline 2 & $2014 / 2015$ & 16 & 53 & 43 & 10 & 122 \\
\hline 3 & $2015 / 2016$ & 19 & 48 & 44 & 14 & 125 \\
\hline 4 & $2016 / 2017$ & 14 & 55 & 43 & 10 & 124 \\
\hline
\end{tabular}

Source: Middle School IT Religion Teacher

From the information provided by the Office of Education school supervisors, it is found that the problems in religious learning so far, teachers still use achievements orally (lectures) or discussions without elaborating in depth the material being studied. Teachers tend to be textoriented and use conventional models even though the media is an intermediary tool that makes it easier for teachers to present more interesting material and make students more motivated in learning what else when middle school age.

\section{Review of Literature}

\subsection{Learning outcomes}

Learning is an attempt by someone to obtain a new change in behavior as a whole, as a result of his own experience in interaction with the environment. There are several opinions regarding the definition of learning put forward from several learning theories, among others, according to the theory of behaviorism and the theory of cognitive. 
According to Bigge (1982: 52) states that learning is a change in behavior as a result of the interaction between stimulus and response. In other words, learning is the change experienced by students in terms of their ability to behave in new ways as a result of the interaction between stimulus and response. Behaviorism theorists assume someone has learned something if someone can show changes in behavior. According to this theory, the most important thing is input or input in the form of stimulus and output or output in the form of response. Stimulus is anything given by the teacher to students such as teaching aids, work guidelines, or certain ways to help student learning, while the response is the reaction or response of students to the stimulus provided by the teacher.

The purpose of learning according to the theory of behaviorism is emphasized on the addition of knowledge, while learning as a "mimetic" activity, which requires students to reexpress knowledge that has been learned in the form of reports, quizzes, or tests. Learning evaluation is seen as a separate part of learning activities, and is usually done after the learning activities are completed. This theory emphasizes evaluating individual students' abilities.

\subsection{The Nature of Learning Aqeedah Morals}

This aqeedah subject is a branch of Islamic education, according to Zakiyah Daradjat Islamic education is an effort to foster and care for students so that they can always understand the teachings of Islam as a whole. Then live the goal that in the end can practice and make Islam as a way of life.

Aqeedah in terms of language (etymology) means "bond". Aqeedah someone, meaning "bonding someone with something". The word aqeedah comes from Arabic, aqoda-ya'quduaqidatan. Meanwhile, according to the term aqeedah, that is, the belief or belief in something in each person's heart that makes the heart calm. (Yumansyah, 2008: 3).

The word etymology is etymologically derived from Arabic, the plural form of the word khuluq or al-khulq which in language means, among other things, character, temperament, behavior, or character. In essence khulq (character) is a condition or trait that has permeated the soul and become a personality until from that arises various kinds of actions in a spontaneous and easy way without being made up and without thinking. Then Ibnu Athir, as revealed by Humaidi Tatapangarsa, said that the essence of khuluq's meaning is an exact human inner description (attitude and nature), while kholqu is a description of its outer form (facial expression, skin color, height, body height, etc.). So based on the perspective of the validity of the essence of morality in everyday terms is equated with manners, decency, manners, manners (Indonesian version), whereas in English it is equated with morals or ethics. According to Greek the term morality is influenced by the term Ethos, or Ethicos or ethics (without using the letter $\mathrm{H}$ ) which implies an ethical meaning which means human effort to use reason and power, he thought to solve the problem of how he should live if he wants to be good. And ethics is a science not a teaching.

From the above understanding we can know the use of the first morality is related to human faith, while the second relates to worship which is an embodiment of the Faith, if these two things are separate then, morals will damage the purity of the soul and human life. Moral is very important for human life, the importance of aqeedah is not only for humans in their status as individuals, but also means for family and community life even for the life of the nation and state.

Morals are the pearl of life that distinguishes humans from animals. To develop aqeedah morals for students or adolescents needed modification of moral elements with cultural factors where children live. Moral teaching programs should be adjusted to the characteristics of these 
students, which include moral elements are 1) Moral inheritance, 2) Feelings, 3) Moral behavior and 4) Existential belief / faith. Aqeedah moral education is a conscious and planned effort in preparing students to recognize, understand, appreciate and believe in Allah SWT and to realize it in noble moral behavior in daily life based on the Qur'an and Hadith through activities of guidance, teaching, training and use experience. Accompanied by guidance to respect adherents of other religions and their relationship with harmony between religious communities in the community to realize the unity and integrity of the nation.

\subsection{The Nature of the Point Conterpoint Learning Model}

In language, the model can be interpreted as a strategy, tips, tricks or ways. Fathurrahman (2007: 3). While the Model in general is a plan about the utilization and use of existing potential and means to improve the effectiveness and efficiency of teaching. Slameto (2010: 76). Literally, the word "Model" can be interpreted as art (art) carrying out strategy that is strategy or plan. In the perspective of Psychology, said the Greek-derived model, means an action plan consisting of a set of steps to solve a problem or achieve a goal. While what is called Learning is to teach students to use the principles of education and learning theory is the main determinant of educational success. Learning is a two-way communication process, teaching is carried out by the teacher as an educator, while learning is carried out by students or students. (Muhibbin Syah, 2007: 214).

According to Dick and Carey (2009: 32) Learning Model is not only limited to the procedure of activities, but also includes the material or teaching package. This model can be applied if the teacher wants to present a topic or problem that raises a variety of different views. Therefore convey the topic to students and ask for their opinions or views. After knowing the various views of students, group students according to their views. Make sure they sit separately to foster a healthy atmosphere of discussion or debate. Whereas Point Conterpoint means contending opinions in accordance with perspective, this model is a technique to stimulate discussion and gain a deeper understanding of various complex issues.

\subsection{The Purpose of Implementing the Point Conterpoint Learning Model}

The purpose of applying the Point Conterpoint learning model is to train students to look for strong arguments in solving an actual problem in the community according to the position played. (Ismail, 2009: 79).

Silberman (2006: 30) says that this model is an activity with powerful techniques to stimulate discussion and gain a deeper understanding of various complex issues of the format is similar to a debate but less formal and runs faster. The same thing was stated by Hisham Zaini (2007: 42) that the Point Conterpoint Learning Model is an excellent learning process used to involve students in discussing group issues in depth. From the explanation of the theory above it can be concluded that the Point Conterpoint learning model is an approach in learning by means of discussion that has similarities with the opinions, only in the Point Conterpoint learning model the learning atmosphere tends to be more free and not too formal. This model is also very well used to involve students in discussing complex issues in depth. Thus it is possible for students to have the freedom to express or express opinions in the discussion process.

Basically, the point Conterpoint learning model can be used in every subject, because this model is a model that stimulates student motivation in learning, but the point Conterpoint learning model will be more effective if applied to the subject of life confusion can be taken as an example of the issue of the MUI fatwa on its forbidden to smoke. So it can be concluded 
that this learning model can be applied to the lessons of Religion, Islamic Education, and Islamic religious education and so on.

So the Point Conterpoint learning model is a way in the learning process that provides opportunities for students to actively argue (submit ideas, ideas) from problems that arise or deliberately raised in learning in accordance with existing rules.

\subsection{The Nature of the Expository Learning Model}

Learning that emphasizes the process of delivering material verbally from a teacher to a group of students with the intention that students can master the lesson optimally. Expository learning model is the same as the direct learning model (directinstruction). Because in this model the subject matter is delivered directly by the teacher. Students are not required to find the material. Material as if it had already been made. Therefore, the expository model emphasizes the process of speaking, so it is often called the term chalk and talk model.

"Direct learning is developed from behavioristic learning theory. Behavioral learning theories have contributed significantly to the direct learning model. The direct learning model is a teaching approach that can help students learn and master basic skills and obtain information step by step. The basic skills in question can be in the form of cognitive and psychomotor aspects as well as other information which is the basis for building more complex learning outcomes ". Fathurrohman (2015: 166)

\section{Research Method}

This research was conducted at Deli Serdang IT Middle School, Percut Sei Tuan District. Deli Serdang Regency, North Sumatra Province. This research was conducted in Odd semester of the 2019/2020 school year with treatment given 4 meetings. For one meeting, it took 2 x 40 minutes.

Population is the entire subject of Arikunto research (2002: 108) The population in this study were all grade VII students in AL Hijrah IT Middle School and Salsabila IT Middle School in Percut Sei Tuan District. Deli Serdang Regency, North Sumatra Province, where IT AL-Hijrah Junior High School consists of 2 classes with a total of 50 students. And Salsabila IT Middle School consists of 2 classes and the total number of students is 50 students.

Table 2. Total Population

\begin{tabular}{|l|l|l|}
\hline No & SMP IT HIJRAH & Total Students \\
\hline 1 & Class VII- A & 24 \\
\hline 2 & Class VII- B & 26 \\
\hline & Total & $\mathbf{5 0}$ \\
\hline & SMP IT SALSABILA & \\
\hline 1 & Class VII- A & 26 \\
\hline 2 & Class VII- B & 24 \\
\hline & & $\mathbf{5 0}$ \\
\hline
\end{tabular}

Testing the statistical hypothesis for the Point Conterpoint learning model and the Expository learning model is as follows:

$\mathrm{H}_{0}: \mu \mathrm{A} 1 \leq \mu \mathrm{A} 2$

$\mathrm{H}_{\mathrm{a}}: \mu \mathrm{A} 1>\mu \mathrm{A} 2$ 
With the sentence can be written:

$\mathrm{H}^{0}$ : Aqeedah learning outcomes of students who are taught with the Point Conterpoint learning model is lower or equal to Aqeedah learning outcomes of students who are taught with the Expository learning Model.

$\mathrm{H}^{\mathrm{a}}$ : Aqeedah learning outcomes of students who are taught with the Point Conterpoint learning model is higher than Aqeedah learning outcomes of students who are taught with the Expository learning Model.

From the data calculation results, the average learning outcomes of Aqeedah students taught by the Point Conterpoint learning model is 33.11 and the standard deviation is 3.58 while the average learning outcomes of Aqeedah students who are taught with the Expository learning Model is 30.02 and the standard deviation 3.51.

The results of analysis of variance showed between the two average learning outcomes of Aqeedah students with two learning models there were significant differences at the significance level of 0.05 where $\mathrm{F}^{\text {count }}=17.64$ while $\mathrm{F}^{\text {table }}=3.94$ so that $\mathrm{H} 0$ was rejected and Ha was accepted. Thus it can be concluded that the ability of Aqeedah student learning outcomes taught by the Point Conterpoint learning model is higher than the Aqeedah learning outcomes of students who are taught with the Expository learning Model.

\section{Discussion}

The highest value of the ability of Aqeedah students who were taught with the Point Conterpoint learning model was 38 and the lowest value was 26 . With the sturges technique obtained range 12, the number of class intervals 7 and the length of the class interval 2. List of the frequency distribution of learning outcomes Aqeedah students who learned with the Point Conterpoint learning model can be seen in the following table 3.

Table 3. Distribution of student learning outcomes Aqeedah learning with the Point Conterpoint learning model.

\begin{tabular}{|c|c|c|}
\hline Class Interval & Fi & Relative Frequency (\%) \\
\hline $26-27$ & 4 & 7,69 \\
\hline $28-29$ & 5 & 9,62 \\
\hline $30-31$ & 8 & 15,38 \\
\hline $32-33$ & 11 & 21,15 \\
\hline $34-35$ & 9 & 17,31 \\
\hline $36-37$ & 8 & 15,38 \\
\hline $38-39$ & 7 & 13,46 \\
\hline & $\mathbf{5 2}$ & $\mathbf{1 0 0 , 0 0}$ \\
\hline
\end{tabular}

With the results of basic statistical calculations obtained an average value $=33.11$, median value $=33.10$ mode value $=32.70$ standard deviation $=3.58$ and variance value $=$ 12.79. Based on table 4.1. It was obtained $32.69 \%$ of students who had Aqeedah learning outcomes below average, and $46.15 \%$ of students who had Aqeedah learning outcomes above average. The Aqeedah learning outcomes of students who are taught with the Point Conterpoint learning model can be seen in the following histogram. 


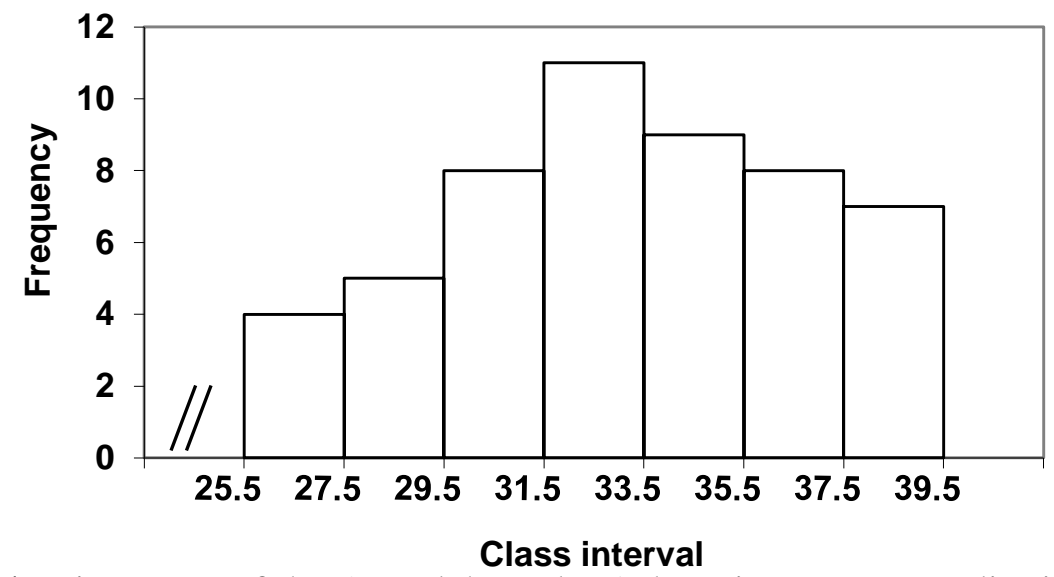

Figure 1. Histogram of the Aqeedah student's learning outcomes distribution frequency which is taught with the Point Conterpoint learning model.

From the results of the ideal value with three categories in Aqeedah learning outcomes students using the Point Conterpoint learning model tend to fit into the medium category.

Based on the results of research conducted for Aqeedah Learning Outcomes students who were taught with the Point Conterpoint learning model obtained an average score of 33.17 while students who were taught with the Expository Learning Model only gained an average of 30.63. Learning Outcomes Aqeedah students who are taught with the Point Conterpoint learning model are higher than the average value of students who are taught with the Expository learning Model. Which is reinforced by the results of the Scheffe test calculation. This indicates that the Point Conterpoint learning model is better at increasing students' understanding of Aqeedah compared to the Expository learning Model. This shows that to teach Aqeedah subject matter it is better to use the Point Conterpoint learning model compared to the Expository learning Model.

In the learning process every teacher must have the ability in an effort to create a pleasant and conducive learning atmosphere. In order to create a pleasant and conducive learning atmosphere it is not easy, because it requires knowledge and skills on how to create a conducive and pleasant classroom atmosphere, one of the efforts for that is to use a learning model that is inseparable from the characteristics of the students being taught, because if the teacher knows student characteristics, the teacher will know the learning model that will be used. As in research by Made (2014) that the effect of learning Point Conterpoint with mind mapping teaching on mathematics learning skills has a very significant influence. Thus the teacher can apply the learning model appropriately and know the needs of students which will improve student learning outcomes Aqeedah and also be able to achieve learning objectives well.

Learning model is a model for organizing learning content that refers to ways to choose and apply subject matter in a meaningful structure. As a variable in learning, the learning model is very influential in improving student learning outcomes Aqeedah.

Aqeedah lessons are very interesting if taught by using the Point Conterpoint learning model so that it will make it easier for students in learning to be taught by the teacher or after being taught by the teacher in addition to students can use the time by using the In focus tool for learning, student learning outcomes will appear more clearly when students are able to be active and innovative individually with the monitoring of parents of students and teachers, the 
Budapest International Research and Critics in Linguistics and Education (BirLE) Journal Volume 2, No 4, November 2019, Page: 514-524 e-ISSN: 2655-1470 (Online), p-ISSN: 2655-2647 (Print) www.bircu-journal.com/index.php/birle emails: birle.journal@gmail.com birle.journal.qa@gmail.com

ability of students will be further improved and train students to interact by using the Point Conterpoint learning model.

In this study, based on the first hypothesis testing, it was obtained that the application of the Point Conterpoint learning model had a significantly different effect on the learning outcomes of Aqeedah where $\mathrm{F}^{\text {count }}>\mathrm{F}^{\text {table }}$ so that for the first research hypothesis Ha was accepted and $\mathrm{H} 0$ was rejected. Therefore, the Expository Learning Model is less effective to facilitate students in learning because in this learning there is no positive interdependence so that the knowledge they gain is not as much as that obtained by students who use the Point Conterpoint learning model. So from this study it is clear that the Point Conterpoint learning model will give a better influence on the learning outcomes of Aqeedah compared to the Expository learning Model.

The findings of this study also support previous research conducted by Prayekti (2014) who examined the Point Conterpoint learning approach to improve the learning outcomes of high school students. Then research by the use of the Point Conterpoint learning model greatly encourages the improvement of students' Aqeedah learning outcomes and enhances the ability of students to learn independently on the Aqeedah subjects of MAN Medan City.

\section{Conclusions}

Based on the results of research and discussion that has been stated previously, then in this study it can be concluded that the Aqeedah learning outcomes of students taught with the Point Conterpoint model are higher than students taught with expository learning models.

\section{References}

Akbar, S. (2013). Instrumen Perangkat Pembelajaran, Bandung : Rosda

Atwi, S, (2014). DesainInstruksional Modern, Jakarta: PenerbitErlangga

Arends, R (1997). Classroom Instructional and Management, New York:MeGraw Hill Book, Arikunto, S. (2002), Produr Penelitian, Jakarta : Rineka Cipta

Ary, D. Jacobs. L.C. \&. Razavieh. A. (2005), Introduction to Research Education $3^{\text {rd }}$. New York : Halt Rinerhart and Winston

Bandura, A. (1997). Self Efficacy Encylopedia Of Human Behavior. 4.(81).

Banna, H.AL. Majmuatuar-Rasail (Beirut:Muassasahar-Risalah, $t$ t)

Bloom, Benjamin, S.etc. (1956). Taxonomy of Educational Objektives :TheClassisification of Educational Goals. Hancook I Cognitive Domain. New York: Longmans. Green and Co.

Bigge, \& Morris L. (1982). Learning Theories for Teachers (4 ${ }^{\text {Th }}$ Edition). California State University, Fresno: Harper \& Row, Publisher,

Bruner, Jerome S., (1996). The Process of Education ( $2^{\text {th }}$ edition). London: Harvard University Press.

Dick, W and L. Carey, J. O. Carey. (2009). The Systematic Design of Instruction (7 ${ }^{\text {th }}$ ed). Newyork: Pearson.

Fathurrohman, M., (2015). Model - Model Pembelajaran Inovatif-Alternatif Desain Pembelajaran Yang Menyenangkan. Yogyakarta : AR-Ruzz Media.

Feist. J. GregoryJ.Feist, (2008). Theories Of Personality, terj. YudiSantosoS.Fil, Yogyakarta: Pustaka Pelajar .

Gagne. Robert M. (1997). Conditions of learning. New York : HoltRinehard and Winston 
Budapest International Research and Critics in Linguistics and Education (BirLE) Journal Volume 2, No 4, November 2019, Page: 514-524 e-ISSN: 2655-1470 (Online), p-ISSN: 2655-2647 (Print) www.bircu-journal.com/index.php/birle emails: birle.journal@gmail.com birle.journal.qa@gmail.com

Gall, Joyce P. (2007).Educational Research An Introduction ( $8^{\text {th }}$ edition). United States of America: Pearson Educational, Inc.

Gunawan, R. (2014). Sejarah Indonesia., Jakarta, Kementerian Pendidikan dan Kebudayaan. Hamalik O. (2014). Proses BelajarMengajar.Jakarta :GunungAgung

Hamid, A. K. (2014). Teori Belajar dan Pembelajaran. Medan: PPs Unimed.

Lundgren, Linda, (1994). Cooperatif Learning in The Science Classroom. GLECEO 1 Macmillan/ Mcgrow-Hill

Majid, A. (2004). Pendidikan Agama Islam Berbasis Kompentensi Konsep Dan Implementasi Kurikulum 2004. Bandung : PT Remaja Rosdakarya.

Marzban, A. Alinejad, F. (2014). The Effect of Cooperative Learning on Reading Comprehension of Iranian EFL Learners.Procedia-Socialand Behavioral Sciences.116: $3744-3748$

Marno, M. Idris, (2008). Strategi \& Metode Pengajaran;Menciptakan Keterampilan Mengajar yang Efektif dan Edukatif, Yogyakarta : Ar-Ruzz

Motaei, B. (2014). On the Effect of Cooperative Learning on General English Achievement of Kermanshah Islamic Azad University Students.Procedia-Socialand Behavioral Sciences 1249-1254

Muhaimenet at. (2005), Kawasandan Wawasan Study Islam, Jakarta: Kencana Wardana Media,

Miarso, Y. (2004). Menyemai Benih Teknologi Pendidikan. Jakarta: Kencana Prenada Media Group.

Miller, Jhon P. (1985). Curriculum perspectives and practice. New York \& London: Longman Inc.

Mukhid, A. (2009). Self-Efficacy (Perspektif Teori Kognitif Sosial dan Implikasinya terhadap Pendidikan.Tadrîs.4(1) 108-109

Musta'an, (2015). Meneliti Tentang Pengaruh Strategi Pembelajaran Point Conterpoint Terhadap Hasil Belajar Mata Pelajaran FiqihSiswa MAN Karang gede Tahun 2014/2015. Jurnal Ilmiah Ekonomi Islam, 1(3) 161-167

Ngalimun, (2014). Strategi dan Model Pembelajaran. Yogyakarta :Aswaja Pressindo

Panjaitan, M.A. (2015). Perbandingan Hasil Belajar Siswa Yang Diajar Dengan Strategi Pembelajaran Contekstual Teaching Learning (CTL) Dengan Yang Diajar Dengan Strategi Pembelajaran Ekspositori Pada Materi Sistem Transportasi Darah SMP Swasta PAB 9 T.P. 2014/2015. Jurnal Penelitian Pendidikan 3(4) 2338 - 3003

Pidarta, M. (2009). Landasan Kependidikan-Stimulus Ilmu Pendidikan Bercorak Indonesia. Jakarta : Rineka Cipta

Pulungan, I. \& Istarani, (2015). Ensiklopedi Pendidikan. Medan : Media Persada

Rahmiliwati, Hasan. (2015). Pengaruh Strategi Pembelajaran dan Kepercyaan Diri Terhadap Hasil Belajar Ekonomi. Teknologi Informasi dan Komunikasi dalam Pendidikan. 2(2) $2355-4983$

Reigeluth C, M. (1983). Instructional Design Theories and Model: An Overview of their Current Status. London: Lawrence Erlbaum Associates, Publisher.

Riyanto, H.Y. (2015). Paradigma Baru Pembelajaran, Jakarta :Kencana Prenada Media Group,

Rustika, M. (2012). Efikasi Diri: Tinjauan Teori Albert Bandura. Fakultas Psikologi Universitas Gadjah Mada Volume 20 (2) 0854-7108

Rusman, (2012). Model-Model Pembelajaran Mengembangkan Profesionalisme Guru. Jakarta : PT Raja Grafindo Persada 
Budapest International Research and Critics in Linguistics and Education (BirLE) Journal Volume 2, No 4, November 2019, Page: 514-524 e-ISSN: 2655-1470 (Online), p-ISSN: 2655-2647 (Print) www.bircu-journal.com/index.php/birle emails: birle.journal@gmail.com birle.journal.qa@gmail.com

Sabiq, S. (2004). Akidah Islam, terj. Moh.Abdai Rathomy, cet, XIV. Bandung: Diponegoro

Sang, Eun Yoo. (2015). Astudy on Jigsaw Model Aplication in Teaching and Learning Mathematics. Jurnal Internasional19(4) 195-198

Sare Şengül dan Yasemin Katranci, (2013). "Effects of Jigsaw Technique on Mathematics Self-Efficacy Perceptions of Seventh Grade Primary School Students" Social and Behavioral Sciences. 116. 333-338

Setyowati, C. (2018). Pengaruh Strategi Pembelajaran dan Motivasi Belajar terhadap Hasil Belajar Bahasa Indonesia Peserta Didik Kelas IX SMP Tarakanita 4 Jakarta.Jurnal Ilmiah Wahana Pendidikan 4(4)

Siagian, S, Tanjung, P. (2015): Pengaruh Strategi Pembelajaran dan Gaya Belajar Terhadap Hasil Belajar IPA Kelas VIII Siswa SMP Negeri 1 Dolok Panribuan. jurnal Teknologi penDidikan. 5(2) 1979 - 6692

Sudjana. (2008). Penilaian Hasil Proses Belajar Mengajar, Bandung: PT. Remaja Rosdakarya. Suparno, P. (2008). Teori Filsafat Kontruksivisme dalam Pendidikan.Yogyakarta :Kanisius

Suprijono, A. (2009). Cooperative Learning, Yogyakarta : Pustaka Belajar

Slameto, (2010). Belajar dan Faktor-Faktor Yang Mempengaruhi. Jakarta :Rineka Cipta.

Slavin. (1994). Cooperatif Learning.Boston London: Allyn and Bacon

Sukmadinata, N. (2011). Landasan Psikologi Proses Pendidikan. Bandung: Remaja Rosdakarya.

Suparman, A. (2014). Desain Instruksional Modern-Panduan Para Pengajar dan Inovator Pendidikan. Jakarta :Erlangga

Sugiyono. (2016). Metode Penelitian Pendidikan (Pendidikan Kuantitatif, Kualitatif, dan $R \& D)$. Bandung: Alfabeta

Suparno.(1997). Filsafat Konstruktivisme dalam Pendidikan. Yogyakarta: Kanisius.

Suprijono, A. (2009). Cooperative Learning - Teori dan Aplikasi Paikem. Yogyakarta :Pustaka Belajar

Syah, M. (2010). Psikologi Pendidikan dengan Pendekatan Baru. Bandung: Remaja Rosdakarya.

Thordike, E.L. \&. Hagen. Measurement and Evaluation in Psychology and Education, New York: John Wiley.

Tuckman.B.W. (1978). Conducting Educational Research. Second Edition. New York: Harcourt Brace Jovanovich

Trianto, (2009) .Mendesain Model Pembelajaran Inovatif-Progresif.Surabaya :Kencana Prenada Media Group.

Uno, B. Hamzah, (2008). Orientasi Baru dalam Psikologi Pembelajaran. Jakarta: Bumi Aksara

Prayekti. (2014). The influences of stad cooperative learning vs expository and Cognitive style on learning outcomes of physics concept Grade x senior high school student. Jurnal Pendidikan dan Kebudayaan, 20(4) 67-80

Yamin, Martinis . (2010). Kiat Membelajarkan Siswa. Jakarta :Gaung Persada Press

Yeni, \& Dwi M. (2014), Pendekatan Hands On Activity Melalui Modified Inquiry Untuk Meningkatkan Self Efficacy Siswa Kelas XI MAN 1 Tuban. Unesa. Journal of Chemical Education 13(1) 2252-9454

Yumansyah, T. (2008). Buku Aqeedah Akhlak, Jakarta: Grafindo Media Pratama,

Setiawan, W.D. (2017). Pengaruh Penggunaan Model Pembelajaran Kooperatif Tipe Teams Games Tournament dan Model Pembelajaran Ekspositori Terhadap Hasil Belajar Pendidikan Kewarganegaraan 4(1) 
Wahyuhadi, I.R. (2015) . Hubungan Antara Penyesuaian Diri Di Sekolah Dengan Kepercayaan Diri Pada Siswa Kelas X MAN 1 Kota Magelang. Jurnal Bimbingan dan Konseling

Widiari, M., (2014). Pengaruh Metode Pembelajaran Mind Mapping dan Ekspositori terhadap Hasil Belajar Matematika di SD Gugus IX Kecamatan Buleleng. Journal Edutech Universitas Pendidikan Ganesha Jurusan Teknologi Pendidikan 2(1) 27-89

Sanjaya. W. (2006). Strategi Pembelajaran. Jakarta: Kencana,

Sunarto, W. (2008). Hasil Belajar Kimia Siswa dengan Model Pembelajaran Metode ThinkPair-Share dan Metode Ekspositori. Jurnal Inovasi Pendidikan Kimia2(1) 244-248

Zaini, H. (2008). Strategi Pembelajaran Aktif, Yogyakarta: Insan Madani

Zahruddin A R. Sinaga, H. (2004). Pengantar Studi Akhlak. Jakarta : PT Raja

Grafindo Persada, 